Available online at: https://proceeding.researchsynergypress.com/index.php/cpmhs/index

RSF Conference Series: Medical and Health Science

e-ISSN (to be processed) / p-ISSN (to be processed)

Volume 1 Number 1 (2021): 127-134

\title{
The Effect of Gymnastics in The Healthy Elderly on Physical Fitness and Cognitive Function in Indonesia Elderly Institutional of West Java Province
}

\author{
Hilman Triyadi Kusumah1, Ieva B. Akbar², Alya Tursina³ \\ ${ }^{1}$ Prodi Pendidikan Dokter, Faculty of Medicine, Universitas Islam Bandung, Indonesia \\ ${ }^{2}$ Departemen Physiology, Faculty of Medicine, Universitas Islam Bandung, Indonesia \\ ${ }^{3}$ Departemen Neurology, Faculty of Medicine, Universitas Islam Bandung, Indonesia
}

\begin{abstract}
The declines in physical fitness and cognitive function are two of the indicators that can be used in determining the health status of the elderly. According to Statistics Indonesia, the number of elderly people in Indonesia reached 20.24 million people in 2014. The Elderly will likely be more vulnerable to physical complaints due to the aging process. Gymnastics is an appropriate type of exercise for the elderly and has good benefits to improve the quality of life, maintaining their physical fitness and cognitive function. The purpose of this study is to determine the effect of gymnastics of healthy elderly on physical fitness and cognitive function in Lembaga Lanjut Usia Indonesia (Indonesia Elderly Institutional) of West Java Province. This research was conducted from February to June 2017. The research method is analytical observational with a cross-sectional design. The samples of research were 20 people who regularly attend gymnastics and 20 people who do not regularly attend gymnastics. Their age ranges between $60-69$ years old. Measurements of fitness used in this study was a Six-minute walk test, while for cognitive function, Mini-Mental State Examination (MMSE) was applied. The results showed that 18 out of 20 people who exercised gymnastics on a regular basis had good physical fitness (VO_2max $=24,01-30,59 \mathrm{ml} / \mathrm{kg}$ $\mathrm{BW} / \mathrm{min}$ ), and all of them had normal cognitive function (MMSE score between 24-30). As for chi-square test results, it was shown that the elderlies who performed regular physical fitness exercise had $p<0,05$, while their cognitive function had $p<0,05$. In conclusion, there is a positive impact of gymnastics on the healthy elderly's physical fitness and cognitive function. The elderly who regularly attend gymnastics has chronic adaptation resulted in good physical fitness. In addition, gymnastics is a combination of muscle movement and breathing exercises, and it maximizes the blood flow and oxygen supply to the brain that results in better cognitive function.
\end{abstract}

Keywords: Gymnastics, Healthy elderly, Physical Fitness, Cognitive Function

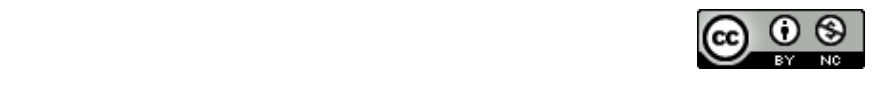

This is an open access article under the CC-BY-NC license

\section{INTRODUCTION}

Indicators of the success of health development in a country can be seen from the benchmark of progress in improving the quality of life and increasing health status, one of which is the number of elderly people from year to year. This success can be seen from the increase in life expectancy and the increasing number of elderly people from year to year. Since 2000 Indonesia has been included in the group of countries with an old structure due to the increasing number of elderly people.1 The World Health Organization (WHO) estimates that Between 2015 and 2030, there will be an increase of 60\% in the number of elderly people in Asia and Africa. 2 According to the Indonesian Central Bureau of Statistics, the

Corresponding author

Alya Tursina, alya.fkunisba@gmail.com

DOI: (to be processed)

Research Synergy Foundation 
number of elderly people in Indonesia reached 20.24 million, equivalent to $8.03 \%$ of the entire population of Indonesia in 2014.3

With age, the body's physiological functions decline due to the aging process. This can be overcome through the WHO's active aging concept, which aims to build elderly people who are physically, socially, and mentally healthy despite the aging process still happens.4 Aging is a life cycle process that describes a person who is getting older.5

Aging can be recognized from changes in the body, both physically and psychologically. Physical changes in the elderly include the five senses consisting of eyes, ears, smell, taste, in addition to changes in the brain, lungs, gastrointestinal, urinary tract, bones, cardiovascular, and others. Not only physical changes that occur in the elderly, but psychological factors will also experience significant changes. Psychological changes that can occur include paranoia, behavior disorders, depression, post-power syndrome, sleep disorders.6

The aging process occurs in all tissues, including the nervous system, either anatomically or neurophysiologically, which changes the structure of the brain so that cognitive function declines. $7 \mathrm{~A}$ healthy and fit physical state can be obtained through regular exercise. 8

According to Occupational Medicine and Health Affairs, exercise is one of the important factors in maintaining body balance, increasing physical fitness, and increasing muscle work capacity in the elderly.

Regular exercise has positive benefits for the elderly, such as improving physical health, cognitive function, effectiveness in communication, and behavior. About $10 \%$ to $20 \%$ of the elderly worldwide experience cognitive decline, so that it becomes one of the health problems that extends throughout the world.10

Elderly gymnastics is a sport that is adapted to the elderly's physique and is easy to do. Elderly exercise is a combination of muscle movement and breathing techniques so that it can maximize the flow of blood and oxygen to the brain.11

Based on research by Lawrence Robinson (2016) shows that exercising can improve cognitive function and maximize brain function.12 According to the American Medical Association, regular physical activity results in better cognitive function in the elderly.13

Based on the background that has been described, the authors are interested in conducting research on the effect of exercise on healthy elderly people on physical fitness and cognitive function at the Indonesian Elderly Institute in West Java Province.

\section{RESEARCH METHODOLOGY}

This study was conducted using an observational analytic method with a cross-sectional approach to determine whether there is an influence of elderly exercise on physical fitness level using the Six-minute walk test (6MWT) assessment method, while to determine the effect of elderly exercise on cognitive function using the Mini-mental state method. Examination (MMSE).

The Six-Minute Walk Test (6MWT) or 6-minute walk test is a physical fitness measurement method that is practical, simple, safe, and easy for the elderly to perform when compared to other types of fitness tests. The purpose of this test is to measure the ability to walk as quickly as possible and as far as possible within 6 minutes. This test does not take long and requires minimal fees, but this 6MWT has the drawback that it is very easy to do by individuals who have excellent physical fitness.14,15,16 Physical fitness level can be assessed from maximum oxygen consumption or V02 max.17 According to Nury Nusdwinuringtyas, to determine the maximum oxygen consumption after a 6-minute walk test, it can be calculated using the formula.18 
RSF Conference Series: Medical and Health Science, Vol. 1 (1), 127-134

The Effect of Gymnastics in The Healthy Elderly on Physical Fitness and Cognitive Function in Indonesia Elderly Institutional of West Java Province

Hilman Triyadi Kusumah, Ieva B. Akbar, Alya Tursina

VO_2 maximum $=0.053$ (distance) +0.022 (age) +0.032 (height) -0.164 (weight) -2.228 (gender: $0=$ male, $1=$ female) -2.287

Mini-Mental State Examination is an assessment method used to measure cognitive function. The MMSE was modified by Folstein in 1975. In this examination, there are five components to be assessed, namely orientation, registration, attention and calculation, recall, and language. This examination takes 510 minutes for each respondent. The interpretation of the MMSE measurement results consists of 3 categories, namely the value 24-30 is interpreted as normal cognitive function, the value 17-23 means experiencing probable or possible cognitive impairment, and the value 0-16 means experiencing definite or confirmed cognitive impairment.19,20

The research sample was 20 healthy elderly people who routinely exercised and 20 healthy elderly people who did not exercise regularly aged 60-69 years who took part in gymnastics at the Indonesian Elderly Institute, West Java Province for the period February - June 2017.

The elderly in this study met the inclusion and exclusion criteria. Inclusion criteria for routine and non-routine elderly groups include healthy elderly women aged 60-69 years, education level at least grade 3 elementary school graduates, attending gymnastics at least six months - 1 year with a frequency of 3-5 times/week (for the elderly group who exercise regularly) or have participated in the exercise for $<1$ month with a frequency of exercise $<3$ times/week (for the elderly group who do not exercise regularly). Exclusion criteria included the elderly who suffer from hearing and visual impairment, experience or have a history of memory impairment (dementia) and stroke, have a history of head trauma, and have diabetes mellitus, heart, lung, hypertension, osteoarthritis genu, and low back pain.

Data analysis was performed using the Statistical Product and Service Solution (SPSS) for Windows version 18.0 at a $95 \%$ confidence level and p-value of 0.05 .

This research has obtained ethical approval from the Ethics Committee of the Faculty of Medicine, Universitas Islam Bandung.

\section{FINDINGS AND DISCUSSION}

In table 1. Characteristics of the elderly based on age in the elderly group who routinely and not regularly exercise between the ages of 60-65 years have an average age that is not much different, namely 63.28 years old with regular exercise with a standard deviation of 1.94 and 63.25 years. The elderly do not exercise regularly, with a standard deviation of 1.94. In contrast to the elderly with an age range of 66-70 years, the average age of the elderly for routine exercise was 66.83 years with a standard deviation of 1.22 and 67.00 years with a standard deviation of 1.41 the elderly did not exercise regularly. Based on the education level of the elderly routinely in gymnastics, the level of education equal to elementary school is $7(63.3 \%)$ more people when compared to the others, while in the non-routine group of gymnastics, the education level is at the junior high school level, the largest is 7 (58.3\%). The average height in both groups was 149.35 meters with a standard deviation of 5.88 meters and 149.03 with a standard deviation of 4.25. The weight characteristics of the two groups were $60.32 \mathrm{~kg}$ with a standard deviation of 11.15 and 59.59 $\mathrm{kg}$ with a standard deviation of 11.81 , respectively. 
RSF Conference Series: Medical and Health Science, Vol. 1 (1), 127-134

The Effect of Gymnastics in The Healthy Elderly on Physical Fitness and Cognitive Function in Indonesia Elderly Institutional of West Java Province

Hilman Triyadi Kusumah, Ieva B. Akbar, Alya Tursina

Table 1. Characteristics of the Elderly by Age, Education, Height, Weight Loss in Indonesian Elderly Institutions in West Java Province

\begin{tabular}{llllll}
\hline \multirow{2}{*}{ Variable } & \multicolumn{2}{c}{ Regular Gymnastics } & \multicolumn{2}{c}{ Not Regular Gymnastics } & \multirow{2}{*}{ P-value } \\
\cline { 2 - 5 } & Average (SD) & $\mathbf{n ~ ( \% )}$ & Average(SD) & n (\%) & \\
\hline Age (years) & $63,28(1,94)$ & $14(46,7)$ & $63,25(1,23)$ & $16(53,3)$ & $0,465^{*}$ \\
$60-65$ & $66,83(1,33)$ & $6(60,0)$ & $67,00(1,41)$ & $4(40,0)$ & \\
$66-70$ & & $7(63,3)$ & & $4(36,4)$ & $0,738^{*}$ \\
\hline Education & & $5(41,7)$ & & $7(58,3)$ & \\
SD & $4(44,4)$ & & $5(55,6)$ & \\
Junior High School & & $4(50,0)$ & & $4(50,0)$ & \\
Senior High School & & $20(50,0)$ & $149,03(4,25)$ & $20(50,0)$ & $0,797^{* *}$ \\
College & $149,35(5,88)$ & $20(50,0)$ & $59,59(11,81)$ & $20(50,0)$ & $0,850^{* *}$ \\
\hline Height (cm) & $60,32(11,15)$ & 20 &
\end{tabular}

Note :*Pearson chi-square, ${ }^{* *}$ Mann-whitney test

Based on the results of the 6-minute walk test, in table 2. information is obtained that the maximum mileage is 723 meters in the exercise routine group and the minimum mileage is 334 meters in the nonroutine group. The average distance for the elderly to exercise routinely is 657.50 meters with a standard deviation of 43.48 , while the elderly who do not exercise regularly are 579.60 with a standard deviation of 109.58.

Table 2. Overview of Elderly Mileage in Indonesian Elderly Institutions in West Java Province

\begin{tabular}{|c|c|c|c|c|c|}
\hline \multirow{3}{*}{ Variable } & \multicolumn{4}{|c|}{ Group } & \multirow{3}{*}{ P-value } \\
\hline & \multicolumn{2}{|c|}{ Regular Gymnastics } & \multicolumn{2}{|c|}{ Not Regular Gymnastics } & \\
\hline & $\begin{array}{l}\text { Average } \\
\text { (SD) }\end{array}$ & n (\%) & $\begin{array}{c}\text { Average } \\
\text { (SD) }\end{array}$ & n (\%) & \\
\hline Mileage $(\mathrm{m})$ & $\begin{array}{r}657,50 \\
(43,48) \\
\end{array}$ & $20(50,0)$ & $\begin{array}{c}579,60 \\
(109,58) \\
\end{array}$ & $20(50,0)$ & $0,014^{*}$ \\
\hline \multirow{3}{*}{ Variable } & \multicolumn{4}{|c|}{ Group } & \\
\hline & \multicolumn{2}{|c|}{ Regular Gymnastics } & \multicolumn{2}{|c|}{ Not Regular Gymnastics } & \\
\hline & Minimum & Maximum & Minimum & Maximum & \\
\hline Mileage $(\mathrm{m})$ & 601 & 723 & 334 & 722 & \\
\hline
\end{tabular}

Noted : *Mann-Whitney test

Table 3. describes the physical fitness level of the elderly, which is calculated based on the Nury Nusdwinuringtyas formula with the output $\mathrm{VO}_{2} 2 \mathrm{max}$, which results are converted into fitness classifications according to Kattus. The average value of VO_2max in the elderly with regular exercise is $26.63 \mathrm{ml} / \mathrm{kg} \mathrm{BW} /$ minute or in the good category (24-34 ml/kg BW/minute), while in the elderly who do not exercise regularly, it is $22.53 \mathrm{ml} / \mathrm{kg} \mathrm{BW} /$ minute or in the category moderate $(18-23 \mathrm{ml} / \mathrm{kg} \mathrm{BW} / \mathrm{min})$. 
RSF Conference Series: Medical and Health Science, Vol. 1 (1), 127-134

The Effect of Gymnastics in The Healthy Elderly on Physical Fitness and Cognitive Function in Indonesia Elderly Institutional of West Java Province

Hilman Triyadi Kusumah, Ieva B. Akbar, Alya Tursina

Table 3. Overview of elderly V O_2max Values Lansia in Indonesian Elderly Institutions in West Java Province

\begin{tabular}{|c|c|c|c|c|c|}
\hline \multirow{3}{*}{ Variable } & \multicolumn{4}{|c|}{ Group } & \multirow{3}{*}{ P-value } \\
\hline & \multicolumn{2}{|c|}{ Regular Gymnastics } & \multicolumn{2}{|c|}{ Not Regular Gymnastics } & \\
\hline & Average & SD & Average & SD & \\
\hline $\begin{array}{l}\dot{\boldsymbol{V}} \boldsymbol{O}_{2 \max } \\
\text { value(ml } / \mathrm{kgBw} / \mathrm{min})\end{array}$ & 26,63 & 2,77 & 22,53 & 6,58 & $0,40^{*}$ \\
\hline \multirow{3}{*}{ Variable } & \multicolumn{4}{|c|}{ Group } & \\
\hline & \multicolumn{2}{|c|}{ Regular Gymnastics } & \multicolumn{2}{|c|}{ Not Regular Gymnastics } & \\
\hline & Minimum & Maximum & Minimum & Maximum & \\
\hline $\begin{array}{l}\dot{\boldsymbol{V}} \boldsymbol{O}_{2 \max } \text { value } \\
(\mathrm{ml} / \mathrm{kgBw} / \mathrm{min})\end{array}$ & 22,6998 & 30,5976 & 9,3906 & 33,6498 & \\
\hline
\end{tabular}

Noted : *Mann-whitney test

Based on table 4. the data were analyzed using the Statistical Product and Service Solution (SPSS) program for Windows version 18.0, obtained a p-value of 0.025 (p-value 0.05), so it can be concluded that there is a statistically significant relationship between gymnastics activities and the level of physical fitness of the elderly. At the Indonesian Elderly Institute in West Java Province.

The effect of gymnastics on the elderly on physical fitness and cognitive function at the Indonesian Elderly Institute can be explained in table 4. below:

Table 4. The Effect of Gymnastics with Physical Fitness Levels in the Elderly At the Indonesian

Elderly Institute, West Java Province

\begin{tabular}{|c|c|c|c|c|c|c|c|c|c|c|c|c|}
\hline \multirow{3}{*}{ Variable } & \multicolumn{11}{|c|}{ Physical Fitness Level } & \multirow{3}{*}{$\begin{array}{c}P \text { - } \\
\text { value }\end{array}$} \\
\hline & \multicolumn{2}{|c|}{$\begin{array}{c}\text { Low } \\
(<13)\end{array}$} & \multicolumn{2}{|c|}{$\begin{array}{c}\text { Fair } \\
(13-17)\end{array}$} & \multicolumn{2}{|c|}{$\begin{array}{c}\text { moderat } \\
\text { e } \\
(18-23)\end{array}$} & \multicolumn{2}{|c|}{$\begin{array}{c}\text { Good } \\
(24-34)\end{array}$} & \multicolumn{2}{|c|}{$\begin{array}{c}\text { Excellen } \\
\text { t } \\
(34+)\end{array}$} & Total & \\
\hline & $\mathbf{n}$ & $\%$ & $\mathbf{n}$ & $\%$ & $\mathbf{n}$ & $\%$ & $\mathbf{n}$ & $\%$ & $\mathbf{n}$ & $\%$ & N $\%$ & \\
\hline Regular & 0 & 0 & 0 & 0 & 2 & 10,0 & 18 & 90,0 & 0 & 0 & & $0,025^{*}$ \\
\hline Gymnastics & & & & & & & & & & & 100,0 & \\
\hline Not Regular & 2 & & 3 & 15,0 & 4 & 20,0 & 11 & 55,0 & 0 & 0 & & \\
\hline Gymnastics & 10, & & & & & & & & & & $\begin{array}{l}20 \\
100,0\end{array}$ & \\
\hline
\end{tabular}

Note : *Uji Chi-square, significant $p$ value $<0,05$

In table 5. the research data were analyzed using the Statistical Product and Service Solution (SPSS) for Windows version 18.0 program obtained a p-value of 0.024 (p-value 0.05 ) so that it can be concluded that there is a statistically significant relationship between gymnastics activities and the cognitive function of the elderly. At the Indonesian Elderly Institute in West Java Province.

Table 5. The Effect of Gymnastics with Elderly Cognitive Functions in Indonesian Elderly Institutions in West Java Province

\begin{tabular}{|c|c|c|c|c|c|c|}
\hline \multirow{3}{*}{ Variable } & \multicolumn{5}{|c|}{ Cognitive Function } & \multirow{3}{*}{ P-value } \\
\hline & $\begin{array}{l}\text { Normal } \\
(24-30)\end{array}$ & $\begin{array}{c}\text { Probable } \\
(17-23)\end{array}$ & & $\begin{array}{l}\text { tive } \\
\text { 6) }\end{array}$ & Total & \\
\hline & $\%$ & $\%$ & $\mathbf{n}$ & $\%$ & $\%$ & \\
\hline
\end{tabular}


RSF Conference Series: Medical and Health Science, Vol. 1 (1), 127-134

The Effect of Gymnastics in The Healthy Elderly on Physical Fitness and Cognitive Function in Indonesia Elderly Institutional of West Java Province

Hilman Triyadi Kusumah, Ieva B. Akbar, Alya Tursina

\begin{tabular}{lccccccccc}
\hline $\begin{array}{l}\text { Regular } \\
\begin{array}{l}\text { Gymnastics } \\
\text { Not Regular } \\
\text { Gymnastics }\end{array}\end{array}$ & 20 & 100,0 & 0 & 0 & 0 & 0 & 20 & 100,0 & $0,024^{*}$ \\
\hline
\end{tabular}

Note : ${ }^{*}$ Uji Chi-square, significant $\mathrm{p}$ value $<0,05$

\section{Discussion}

The results showed that as many as 29 (67.5\%) elderly people who took part in gymnastics at the Indonesian Elderly Institute in West Java Province had a good level of physical fitness. The distribution of the elderly with good physical fitness who routinely participates in gymnastics is 18 (90.0\%) elderly people, while in the non-routine group, there are 11 (55.0) elderly people.

Based on (the V)'0_2maxvalue, The elderly in this study had a VO_2max value between 9,3906 $33,6498 \mathrm{ml} / \mathrm{kgBB} /$ minutes. According to research Nury Nusdwinuringtyas (2011), average VO_2max in female subjects of $19.67 \pm 3.56$ with a minimum value of VO_2max max of 11.74 and a maximum value of 30.34.18 This study is in line with Nilam Betarina (2013) showing the average value of VO_2max of the elderly is 30.1 \pm 7.21 .21 This study was strengthened by Yustika Nur Ichsanna (2017), the elderly fitness as measured by a 6-minute walk test the average value of $\mathrm{VO}$ _2max pre-test in the treatment group was 23.23 and in the control group was 22.84. Value VO_2max group post-test The value of VO_2max posttest in the treatment group increased to 25.84, and in the control group to 23.64.22. This is in line with Abdul Azis Ikhwani's research (2011) on the elderly using the 6-minute walking test. Given walking treatment on VO2 max levels in the elderly.23

According to C. Fajar Sriwahyuniati, gymnastics is an effective, safe, and important alternative for the elderly because by doing sports regularly, the elderly can enjoy their lives and maintain their health and fitness. In addition to participating in gymnastics, physical fitness must be followed by a healthy lifestyle, adequate rest, health check-ups, and not smoking can maximize optimal health.24 According to Djoko Pekik (2006), physical fitness is divided into three categories, namely static fitness, dynamic fitness, and motor fitness.25 According to Anrum Bustami (2003), the benefits of gymnastics can be achieved by fulfilling the frequency of exercise 3-5 times/week, the intensity of the exercise, and the time it takes up to 20-60 minutes for each exercise, and the type of exercise required. The recommended exercise is aerobic, which is adapted to the abilities of the elderly. To achieve maximum results, exercise routines are required at least 8-12 weeks and will stabilize after 20 weeks.8,24

Research conducted by Rachmad Dwi Raharjo and Noortje Anita Kumaat (2015) shows that there is an influence of elderly exercise on physical fitness.26 The results of this study are supported by previous research conducted by Yustika Nur Ichsanna (2017) at the Tegalsari Elderly Posyandu and Advanced Posyandu The age of Lodalang Siswodipuran Boyolali shows that there is more physical fitness in the good category in the elderly compared to other physical fitness categories.22

Exercise also has a very good effect on the brain because it makes the brain more active. In addition, exercise can increase creativity and help prevent memory loss, dementia, and cognitive decline.12 Cognitive problems, including memory, thinking, and language disorders that are influenced by age, gender, aging process, alcohol consumption, chronic illness, anxiety, etc

According to the American Medical Association, regular physical activity can prevent the elderly from declining cognitive function.10 Moderate and heavy physical activity in the elderly can reduce the incidence of cognitive dysfunction after a 2-year cohort study was conducted on the elderly.27 
The elderly in this study had varied cognitive functions. Elderly with normal cognitive function as many as 35 (87.5\%) elderly from 40 people, but only $5(12.5 \%)$ elderly people who have probable or possibly have cognitive impairment. All the elderly in this study were able to answer questions about mentioning the name of the object designated by the researcher on the MMSE form, while as many as five elderly people were unable to describe the image shown on the MMSE form.

The results of this study are supported by research by Siti Rohana (2011), which states that following elderly gymnastics can improve the cognitive abilities of the elderly in the Social Service, Banten Province. Kauh Denpasar that the elderly who take part in gymnastics are 16 times more likely to have a normal cognitive function when compared to the elderly who do not take part in gymnastics.29

\section{CONCLUSION}

The results of the research on the level of physical fitness of the elderly who were calculated based on the Nury Nusdwinuringtyas formula with the output VO_2max showed that 18 elderly people had a good level of physical fitness with the value of VO_2maxbetween $24-34 \mathrm{ml} / \mathrm{kg} \mathrm{BW} /$ minute. The results of the research on the cognitive function of the elderly consisted of 20 elderly people with normal cognitive functions.

\section{REFERENCES}

Ministry of Health of the Republic of Indonesia. Elderly situation and analysis. South Jakarta.2014 May 29;1-7.

Wiley J, Sons. Evidence-based approaches to theory, practice, and policy. Blackburn JA, Dulmus CN, editors. New Jersey; 2007. 3-4 p.

United Nations. World Population Ageing 2015. The Population Division of the Department of Economic and Social Affairs. 2015;1-32.

Ministry of Health of the Republic of Indonesia. The situation of the elderly (elderly) in Indonesia. South Jakarta. 2016;1-12.

Wiley J, Sons. Evidence-based approaches to theory, practice, and policy. Blackburn JA, Dulmus CN, editors. New Jersey; 2007. 23 p.

Yusuf A, Fitryasari R, Endang HN. Keperawatan Kesehatan Jiwa.Ganiarji F, editor. Jakarta Selatan: Salemba Medika; 2015. 243-256 p.

Jacobson M. Developmental neurobiology. 4th ed. Rao MS, Jacobson M, editors. New York: Kluwer Academic / Plenum; 2005. 349-361 p.

Sumintarsih. Gerakan Senam Lansia. 2006. http://www.e-jurnal .com / 2014/ 01/ gerakan senam - lansia . html.

Ruiz-Montero PJ, Chiva-Bartoll O, Martín-Moya R (2016) Effects of Ageing in Physical Fitness. Occup Med Health Aff 4:241. doi:10.4172/2329-6879.1000241

Laurin D, Verreault R, Lindsay J, MacPherson K, Rockwood K. Physical activity and risk of cognitive impairment and dementia in elderly persons Arch Neurol. 2001;58(3):498-504. doi:10.1001/archneur.58.3.498

Widianti AT \& Proverawati A. 2010. Senam Kesehatan. Yogyakarta: Nuha Medika.

Robinson L, Smith M, Segal J. Exercise and fitness as you age. 2016 January;1-9.

Weuve J, Kang JH, Manson JE, Breteler MMB, Ware JH, Grodstein F. Physical activity, including walking, and cognitive function in older women. JAMA. 2004 September 22; 292(12): 1454-1461. doi:10.1001/jama.292.12.1454 
Enright PL. The Six-Minute Walk Test. Respir Care. 2003;48(8): 783-5.

American Thoracic Society. Am J Respir Crit Care Med. Guidelines for the six-minute walk test. May 2014;166:1-5.

Crapo RO, Casaburi R, Coates AL, Enright PL, MacIntyre NR, McKay RT, Johnson D, Wanger JS, Zeballos RJ. ATS statement: Guidelines for the six-minute walk test. Am J Respir Crit Care Med. 2002;166(1):111-7. DOI: 10.1164/rccm.166/1/111

Jheri Turnley, B. S. H. VO2 max : How can an endurance athlete use it to obtain peak performance. 2010. hlm. 1-2.

Nusdwinuringtyas N, Laksmi W, Bachtiar A. Healthy adults maximum oxygen uptake prediction from a six minute

walking test. Med J Indones. 2011. 20 (3): 195-200. DOI: http://dx.doi.org/10.13181/mji.v20i3.452

Galea M, Woodward M. Mini-mental state examination (MMSE). Aust J Physiother. 2005;51(3):198.

Wallace M, Kurlowicz L. The Mini-Mental State Examination (MMSE). Best Pract Nurs Care to Older Adults from Hartford Inst Geriatr Nurs. 1999;(3).

Betarina N. Kebiasaan sarapan, status gizi, status keshatan dan daya tahan jantung paru lansia peserta senam terpadu lansia di Kota Bogor. Fakultas Ekologi Manusia Institut Pertanian Bogor. 2013.

Ichsanna YN. Pengaruh senam lansia terhadap kebugaran lanjut usia di Posyandu Lanjut Usia Tegalsari dan Posyandu Lanjut Usia Lodalang Siswodipuran Boyolali. Fakultas Ilmu Kesehatan Universitas Muhammadiyah Surakarta; 2017.

Ikhwani AA. Pengaruh jalan kaki terhadap VO2 max pada lanjut usia. Fakultas Ilmu Kesehatan Universitas Muhammadiyah Surakarta. 2011.

Sriwahyuniati CF. Menjaga kesehatan dan kebugaran bagi lansia melalui berolahraga. Tersedia dari: http://staff.uny.ac.id/sites

Djoko, Pekik. 2006. Pedoman Praktis Berolahraga Untuk Kebugaran Dan Kesehatan. Yogyakarta: Andi Offset.

Raharjo RD, Kumaat NA. Pengaruh senam lansia terhadap kebugaran lansia di Panti Werdha Majapahit Mojokerto. Fakultas Ilmu Keolahragaan Universitas Negeri Surabaya. 2015;1-5.

Etgen T, Sander D, Huntgeburth U, Poppert H, Förstl H, Bickel H. Physical activity and incident cognitive impairment in elderly persons the INVADE study. Arch Intern Med. 2010; 170(2): 186193. doi:10.1001/archinternmed.2009.498

Rohana S. Senam vitalisasi otak lebih meningkatkan fungsi kognitif kelompok lansia daripada senam lansia di Balai Perlindungan Sosial Propinsi Banten. Jurnal Fisioterapi. 2011; 11(1).

Lanawati. Hubungan antara senam kesegaran jasmani lansia dengan fungsi kognitif dan keseimbangan tubuh di Posyandu Lansia Desa Dauh Puri Kauh Denpasar.[Thesis]. Universitas Udayana.2015. 